\title{
Identifying English Language Needs of Religious Guides at The General Presidency of The Grand Mosque and Prophet's Mosque
}

\author{
Turki Alsolami, tgalsolami@kau.edu.sa, King Abdulaziz University
}

\begin{abstract}
The aim of this study is to identify English language needs for religious guides at The General Presidency of The Grand Mosque and Prophet's Mosque. This study adopted a quantitative approach methodology using needs analysis questionnaire. The quantitative data collection instrument was a questionnaire with (51) participants. SPSS was used as the quantitative data analysis method. Findings showed that listening and speaking were the most important skills, and reading was moderately important, while writing is not important at all. Also, English is greatly rated as a tool to effectively perform their tasks in term of preaching and advising guests and pilgrims. Difficulties are embodied in lacking English language, accents, and proper religious expressions and vocabulary. This study highlights an urgent need for English for Religious Purposes. The study proposes a general guideline for a course design framework based on participants' needs.
\end{abstract}

Keywords: English for religious purposes, ESP, needs analysis, religious guides, Saudi Arabia

\section{A.INTRODUCTION}

The Grand Mosque of Makkah receives millions of Muslims every year. Most of these pilgrims are not Arabic speakers, and resides either to native language or English coming from Asian countries, European countries, African countries, south and North American countries. Since English language is a global language, the level of people providing services to pilgrim should have a good command of English to communicate and respond to pilgrims. Therefore, the role of English in a religious site visited by millions from all over the world is important. Religious guides at The Grand Mosque need to have a higher level of English to convey clear messages and to understand interlocutors whenever English is being used. They need not only a general course in English but also, they need also training on religious English as most of the communication with pilgrims is based 
mostly on religious matters. In return, this will improve the quality of services that are being provided to pilgrims and visitors of The Grand Mosque. Therefore, to understand the English language needs for religious guides (RGs) is essentially vital to plan a tailored program that can enhance the level of communication between pilgrims and RGs. This study aims to identify the English language needs for RGs at The Grand Mosque of Makkah. Additionally. It also aims to propose general guidelines for a proper English language course that suits and fulfils their actual communicative needs with non-Arabic speaking guests and visitors based on their reported English Language needs. This overarching questions for this study are:

1- To what extent English Language is used in the jobs of RGs at The Grand Mosque?

2- How do RGs perceive the importance of English Language skills in their lives and work?

3- What difficulties related to English language are faced by RGs at workplace?

4- What are the English Language activities needed by RGs at workplace?

\section{METHOD}

This section discusses methodology of this study: context, participants, research paradigms, research designs, data collection methods, data analysis methods, and study evaluation. These elements are elaborated and reflected empirically on the study. This study adopts a quantitative research design using a questionnaire to collect from a 
large population information related to their level of English, perceptions, and challenges with English language.

Participants of this study are working in the "Presidency of The Holy Grand Mosque Affairs" in the city of Makkah, Saudi Arabia. It is the most sacred place for all Muslims around the world. One of the services offered, is religious guidance where pilgrim have religious questions or inquiry about right ritual practices and RGs respond them either by visiting their office in The Grand Mosque or inside The Grand Mosque while they are doing their rituals. For this study 51 Religious guides completed an online questionnaire. A convenient sampling strategy was applied to recruit participants for this study from a large population of RGs.

This study adopted and modified an existing questionnaire that was developed by a Saudi Researcher (Alhuqbani, 2008). Alhuqbani (2008) designed semi-structured questionnaire to identifying English language needs of some security sectors in Saudi Arabia. Alhaqbani's questionnaire contains questions related to general information, received training programs, types of needed skills, activities and language, importance of English in workplace and personal life, linguistic difficulties, and recommendations. Types and structures of questions were "yes" and "no" questions, Likert scale, open-ended questions exploring IDs of security officers and recommendations. Some of these items were modified, replaced, and deleted to properly investigate English language of RGs. Additionally, an optional open-ended was devised to each section of questionnaire to get deeper understanding. The original questionnaire was written in English, therefore, this study questionnaire was translated into Arabic and sent to an Arabic language editor specialist for face validity. 
The questioner was sent to all RGs working in the Grand Mosque whom were about 140 RGs. Only 51 RGs filled out the online questionnaire. SPSS software was used to generate descriptive data that include means, and percentages. In addition, a thematic analysis was performed on the qualitative part of the open-ended questions part of the questionnaire.

\section{RESULTS}

\section{Quantitative Findings}

The quantitative data collection instrument was a questionnaire which contained 68 items tackled many issues relevant to ESP for the employees of General Presidency of The Grand Mosque affairs. Total participants are 51 out of 140 employees. These quantitative findings were uploaded to elicit percentages "\%" and frequencies " $p$ " as presented in Table (1-11) followed with explanations.

\section{Need of English at Work}

Table 1 Needs of English at work

\begin{tabular}{|c|c|c|c|c|}
\hline \multirow{3}{*}{ NO. } & \multicolumn{4}{|c|}{ Is there a need for English at Work? } \\
\hline & \multicolumn{2}{|c|}{ Yes } & \multicolumn{2}{|c|}{ No } \\
\hline & $p$ & $\%$ & $p$ & $\%$ \\
\hline 1. & 50 & $98 \%$ & 1 & $2 \%$ \\
\hline
\end{tabular}

In Table 1, Participants were asked about the need of English at their work. This question received "yes" from 50 participants and only one of the total population answered "no", which is $2 \%$. This result indicates that there is a huge need for English language in their work.

In the open-ended question for participants to give reason for "Why English is needed in 
their work", participants revealed that English is important because it is being used by many pilgrims, and it is also needed as the medium of communication with non-Arabic speaking and for advising pilgrims. The following quotes were taken from some of the participants' answers to this question.

"English is an International language and becomes more and more common inside The

Grand Mosque”

"Many of non-Arabic Muslims can speak English well but not Arabic"

"Through my years of serving in The Grand Mosque, I need English because many nonArabic committing religious wrongdoings, so we need to advise them"

English Usage Frequency at Work:

Table 2. Frequency of English

\begin{tabular}{|c|c|c|c|c|c|c|c|c|c|}
\hline \multicolumn{10}{|c|}{ Level of English usage frequency at Work } \\
\hline \multicolumn{2}{|c|}{ Always } & \multicolumn{2}{|c|}{ Usually } & \multicolumn{2}{|c|}{ Sometimes } & \multicolumn{2}{|c|}{ Rarely } & \multicolumn{2}{|c|}{ Never } \\
\hline$p$ & $\%$ & $p$ & $\%$ & $p$ & $\%$ & $p$ & $\%$ & $p$ & $\%$ \\
\hline 8 & $15.7 \%$ & 4 & $7.8 \%$ & 34 & $66.7 \%$ & 3 & $5.9 \%$ & 2 & $3.9 \%$ \\
\hline
\end{tabular}

In Table 2, Participants were also asked in this section about the frequency of using English at work. "Sometimes" received the highest responses by participants which indicate that English Is not highly used in their work, followed by "always" and "usually". These results combined represent 46 participants, which can clearly indicate a considerate level of frequency needed to use English.

\section{Levels of English Language Proficiency}

259 | IJET| Volume. 10, Issue 2. December 2021 Copyright Turki alsolami is licensed under Creative Commons Atrribution-ShareAlike 4.0 International License. 
Table 3. Participants' Levels of English Proficiency

\begin{tabular}{|c|c|c|c|c|c|c|c|c|c|c|c|c|c|}
\hline \multirow{4}{*}{ NO } & \multirow{4}{*}{$\begin{array}{l}\text { Overall } \\
\text { Language, } \\
\text { Skills \& } \\
\text { Subskills }\end{array}$} & \multirow{2}{*}{\multicolumn{12}{|c|}{ Level of Proficiency }} \\
\hline & & & & & & & & & & & & & \\
\hline & & \multicolumn{2}{|c|}{ Excellent } & \multicolumn{2}{|c|}{$\begin{array}{l}\text { Very } \\
\text { good }\end{array}$} & \multicolumn{2}{|c|}{ Good } & \multicolumn{2}{|c|}{ Acceptable } & \multicolumn{2}{|c|}{ Weak } & \multicolumn{2}{|c|}{ Very weak } \\
\hline & & $P$ & $\%$ & $P$ & $\%$ & $P$ & $\%$ & $P$ & $\%$ & $p$ & $\%$ & $p$ & $\%$ \\
\hline 1. & Overall & 2 & $\begin{array}{l}3.9 \\
\%\end{array}$ & 3 & $\begin{array}{l}5.9 \\
\%\end{array}$ & 8 & $\begin{array}{l}15.7 \\
\%\end{array}$ & 12 & $\begin{array}{l}23.5 \\
\%\end{array}$ & 7 & $\begin{array}{l}13,7 \\
\%\end{array}$ & 19 & $37 \%$ \\
\hline 2. & Listening & 2 & $\begin{array}{l}3.9 \\
\%\end{array}$ & 4 & $\begin{array}{l}7.8 \\
\%\end{array}$ & 11 & $\begin{array}{l}21.6 \\
\%\end{array}$ & 7 & $\begin{array}{l}13.7 \\
\%\end{array}$ & 7 & $\begin{array}{l}13.7 \\
\%\end{array}$ & 20 & $\begin{array}{l}39.2 \\
\%\end{array}$ \\
\hline 3. & Speaking & 2 & $\begin{array}{l}3.9 \\
\%\end{array}$ & 1 & $2 \%$ & 9 & $\begin{array}{l}17.6 \\
\%\end{array}$ & 13 & $\begin{array}{l}25.5 \\
\%\end{array}$ & 4 & $\begin{array}{l}7.8 \\
\%\end{array}$ & 22 & $43 \%$ \\
\hline 4. & Reading & 0 & 00.0 & 9 & $\begin{array}{l}17.6 \\
\%\end{array}$ & 2 & $3.9 \%$ & 14 & $\begin{array}{l}27.5 \\
\%\end{array}$ & 5 & $\begin{array}{l}9.8 \\
\%\end{array}$ & 21 & $\begin{array}{l}41.2 \\
\%\end{array}$ \\
\hline 5. & Writing & 1 & $2 \%$ & 5 & $\begin{array}{l}9.8 \\
\%\end{array}$ & 7 & $\begin{array}{l}13.7 \\
\%\end{array}$ & 10 & $\begin{array}{l}19.6 \\
\%\end{array}$ & 3 & $\begin{array}{l}5.9 \\
\%\end{array}$ & 25 & $49 \%$ \\
\hline 6. & Grammar & 0 & 00.0 & 3 & $\begin{array}{l}5.9 \\
\%\end{array}$ & 8 & $\begin{array}{l}15.7 \\
\%\end{array}$ & 14 & $\begin{array}{l}27.5 \\
\%\end{array}$ & 12 & $\begin{array}{l}23.5 \\
\%\end{array}$ & 14 & $\begin{array}{l}27.5 \\
\%\end{array}$ \\
\hline 7. & Vocabulary & 0 & 00.0 & 2 & $\begin{array}{l}3.9 \\
\%\end{array}$ & 7 & $\begin{array}{l}13.7 \\
\%\end{array}$ & 20 & $\begin{array}{l}39.2 \\
\%\end{array}$ & 8 & $\begin{array}{l}15.7 \\
\%\end{array}$ & 14 & $\begin{array}{l}27.5 \\
\%\end{array}$ \\
\hline
\end{tabular}

In Table 3, participants were asked about their level of English in all skills. The results show that over $50 \%$ of the participants indicate that their "overall" English proficiency is either "weak" or "very weak". While the others about 50\% was distributed between "acceptable", "good", "very good", and "excellent". The majority of participants as shown in the table, the number of participants who choose excellent and very good are very low.

In listening, 55\% of participants agreed that their level is either "weak" or "very weak". However, the rest 45\% showed "acceptable", "good", "very good", and "excellent". In speaking, $51 \%$ of the population agreed that their speaking ability is either "weak" or "very weak". While less $48 \%$ indicate "acceptable", "good", "very good", and "excellent". 
In reading, over $51 \%$ of the participants indicate that their reading skill is either "weak" or "very weak". While the rest of participants are allocated on "acceptable", "good", "very good", and "excellent". In writing, over 55\% of community of the study reported that their writing skill is either "weak" or "very weak". Nevertheless, the remnant fractioned over "acceptable", "good", "very good", "excellent".

In grammar, over $51 \%$ reported that "weak" or "very weak", while less than $49 \%$ allocated on "acceptable", "good", "very good", and "excellent". In vocabulary, around 41\% reported their levels are either "weak" or "very weak". Furthermore, around 39\% showed that their level of vocabulary is "acceptable". The other fraction is allotted on "good", "very good", and "excellent".

The results show that despite the importance of English as mentioned previously, the overall of their indicated levels on many of the skills is unsatisfactory for an industry that requires a high command of English. It is clear from the table that most of the participants indicate a weakness in language skills.

The Importance of English

Table 4. Importance of English

\begin{tabular}{|c|c|c|c|c|c|c|c|c|c|c|c|}
\hline \multirow{3}{*}{ NO } & \multirow{3}{*}{$\begin{array}{l}\text { English } \\
\text { Language } \\
\text { Skills }\end{array}$} & \multicolumn{10}{|c|}{ Level of Importance } \\
\hline & & \multicolumn{2}{|c|}{ Very important } & \multicolumn{2}{|c|}{ Important } & \multicolumn{2}{|c|}{ Neutral } & \multicolumn{2}{|c|}{ Less important } & \multicolumn{2}{|c|}{ Not important } \\
\hline & & $p$ & $\%$ & $p$ & $\%$ & $p$ & $\%$ & $p$ & $\%$ & $p$ & $\%$ \\
\hline 1. & Listening & 39 & $76.5 \%$ & 11 & $21.6 \%$ & - & - & - & - & 1 & $2 \%$ \\
\hline 2. & Speaking & 40 & $78.4 \%$ & 9 & $17.6 \%$ & - & - & 1 & $2 \%$ & 1 & $2 \%$ \\
\hline 3. & Reading & 7 & $13.7 \%$ & 26 & $51.1 \%$ & - & - & 16 & $31.4 \%$ & 2 & $3.9 \%$ \\
\hline 4. & Writing & 7 & 13.7 & 9 & 17.6 & - & - & 12 & $23.5 \%$ & 23 & $45.1 \%$ \\
\hline 5. & Grammar & 29 & $56.9 \%$ & 8 & $15.7 \%$ & - & - & 11 & $21.6 \%$ & 3 & $5.9 \%$ \\
\hline 6. & Vocabulary & 35 & $68.6 \%$ & 9 & 17.6 & - & - & 6 & $11.8 \%$ & 1 & $2 \%$ \\
\hline
\end{tabular}

261 | IJET | Volume. 10, Issue 2. December 2021 Copyright Turki alsolami is licensed under Creative Commons Atrribution-ShareAlike 4.0 International License. 
As shown in Table 4, participants were asked to rate the importance of English in all skills. The table illustrates that listening, speaking, grammar and vocabulary rated as “very important" skills with percentages $76.5 \%, 78.4 \%, 56.9 \%$, and $68.6 \%$ respectively. Furthermore, reading was not received as very important, however, it was indicated that it is an important skill by $51 \%$ of the participants. Writing was reported as "less important" or "not important" skill at all. It can be implied from these results that Participants are mostly focusing on communicative skills where Listening and Speaking were of the highest percentage.

\section{The Importance of English by Skill}

In order to improve our understanding the specific needs of each skill, in the questionnaire participants were asked about their needs for each skill separately. Participants were asked to rate the importance of items of each skills, followed by an open-ended question where they can write any other reasons for the importance of those skills in their work.

Table 5. Importance of Listening

\begin{tabular}{|c|c|c|c|c|c|c|c|c|c|c|c|}
\hline \multirow{3}{*}{ NO } & \multirow{3}{*}{ Items } & \multicolumn{10}{|c|}{ Importance of Listening } \\
\hline & & \multicolumn{2}{|c|}{$\begin{array}{l}\text { Very } \\
\text { important }\end{array}$} & \multicolumn{2}{|c|}{ Important } & \multicolumn{2}{|c|}{ Neutral } & \multicolumn{2}{|c|}{$\begin{array}{l}\text { Less } \\
\text { important }\end{array}$} & \multicolumn{2}{|c|}{$\begin{array}{l}\text { Not } \\
\text { important }\end{array}$} \\
\hline & & $p$ & $\%$ & $p$ & $\%$ & $p$ & $\%$ & $p$ & $\%$ & $p$ & $\%$ \\
\hline 1. & $\begin{array}{l}\text { To understand religious } \\
\text { utterances, words and } \\
\text { terms related to Hajj and } \\
\text { Omra. }\end{array}$ & 45 & $88.2 \%$ & 5 & $9.8 \%$ & - & - & - & - & 1 & $2 \%$ \\
\hline 2. & $\begin{array}{l}\text { To understand words and } \\
\text { texts of general English. }\end{array}$ & 41 & $80.2 \%$ & 8 & $15.7 \%$ & - & - & 1 & $2 \%$ & 1 & $2 \%$ \\
\hline
\end{tabular}




\begin{tabular}{|l|l|l|l|l|l|l|l|l|l|l|l|}
\hline 3. & $\begin{array}{l}\text { To understand visitors and } \\
\text { guests of The Grand } \\
\text { Mosque who are non- } \\
\text { Arabic speakers }\end{array}$ & 44 & $86.3 \%$ & 6 & 11.8 & - & - & - & - & 1 & $2 \%$ \\
\hline 4. & $\begin{array}{l}\text { To understand religious } \\
\text { lectures and workshops } \\
\text { related to Hajj and Omra }\end{array}$ & 19 & $37,3 \%$ & 17 & $33.3 \%$ & - & - & 12 & $23.5 \%$ & 3 & $5.9 \%$ \\
\hline 5. & $\begin{array}{l}\text { To understand general } \\
\text { questions and inquiries } \\
\text { raised by guests and } \\
\text { visitors of The Grand } \\
\text { Mosque }\end{array}$ & 44 & $86.3 \%$ & 6 & $11.8 \%$ & - & - & 1 & $2 \%$ & 1 & $2 \%$ \\
\hline
\end{tabular}

As shown in Table 5, participants were asked to rate the importance of the Listening skill in five statements. As shown in table (7), the highest reason for the importance of listening skill which received $88.2 \%$ was "to understand religious texts, words and terms related to Hajj and Omra", followed by two reasons which scored the same percentage $86.3 \%$ "to understand general questions and inquiries raised by guests and visitors of The Grand Mosque" and "to understand visitors and guests of The Grand who are non-Arabic speakers". Another reason which scored by $80.2 \%$ was "to understand words and texts of general English". The least reason which significantly received low rates $37.3 \%$ was "to understand religious lectures and workshops related to Hajj and Umra". These percentages indicate that, participants view Listening skill as highly important for religious and work-related communication.

In the optional open-ended questions section, a very limited number of participants shared their reasons for the importance of listening skill which was mostly related to understanding pilgrims English, as one of the participants mentioned "To understand questions raised by English speakers”.

Table 6. Importance of Speaking

263 | IJET| Volume. 10, Issue 2. December 2021 Copyright Turki alsolami is licensed under Creative Commons Atrribution-ShareAlike 4.0 International License. 


\begin{tabular}{|c|c|c|c|c|c|c|c|c|c|c|c|}
\hline \multirow{3}{*}{ NO } & \multirow{3}{*}{ Items } & \multicolumn{10}{|c|}{ Importance of Speaking } \\
\hline & & \multicolumn{2}{|c|}{$\begin{array}{l}\text { Very } \\
\text { important }\end{array}$} & \multicolumn{2}{|c|}{ Important } & \multicolumn{2}{|c|}{ Neutral } & \multicolumn{2}{|c|}{$\begin{array}{l}\text { Less } \\
\text { important }\end{array}$} & \multicolumn{2}{|c|}{$\begin{array}{l}\text { Not } \\
\text { important }\end{array}$} \\
\hline & & $P$ & $\%$ & $\bar{p}$ & $\%$ & $p$ & $\%$ & $p$ & $\%$ & $p$ & $\%$ \\
\hline 1. & $\begin{array}{l}\text { To use words and } \\
\text { terms related to Hajj } \\
\text { and Omra in } \\
\text { conversations. }\end{array}$ & 43 & $84.3 \%$ & 6 & $11.8 \%$ & - & - & 1 & $2 \%$ & 1 & $2 \%$ \\
\hline 2. & $\begin{array}{lr}\text { To use words and } \\
\text { texts of general } \\
\text { English } & \text { in } \\
\text { conversations. } & \\
\end{array}$ & 38 & $74.5 \%$ & 8 & $15.7 \%$ & - & - & 4 & $7.6 \%$ & 1 & $2 \%$ \\
\hline 3. & $\begin{array}{l}\text { To give clear } \\
\text { information and } \\
\text { instructions to non- } \\
\text { Arabic speakers of } \\
\text { guests and visitors of } \\
\text { The Grand Mosque. }\end{array}$ & 42 & $82.4 \%$ & 7 & $13.7 \%$ & - & - & 1 & $2 \%$ & 1 & $2 \%$ \\
\hline 4. & $\begin{array}{l}\text { To talk about religious } \\
\text { topics and concepts } \\
\text { related to Hajj and } \\
\text { Omra }\end{array}$ & 42 & $82.4 \%$ & 8 & $15.7 \%$ & - & - & - & - & 1 & $2 \%$ \\
\hline
\end{tabular}

In Table 6 as shown, participants were asked to rate the importance of Listening skill in four statements. As shown in table (8), the highest reason for the importance of speaking skill which received $84.3 \%$ was "To use words and terms related to Hajj and Umra in conversations", followed by two reasons which scored the same percentage $82.4 \%$; they are: "To give clear information and instructions to non-Arabic speakers of guests and visitors of The Grand Mosque." and “To talk about religious topics and concepts related to Hajj and Umra. The least reason which received lower rates yet not very significantly different from other reasons was "To use words and texts of general English in conversations" where $74.5 \%$ of the participants view it as very important.

In the optional open-ended questions section, a number of RGs shared their reasons for 
the importance of speaking skill which was mostly related to understanding advising and preaching pilgrims about religious matters, as indicated in the following two quotes:

"To advise wrongdoers using English"

"To preach to the righteous way of the Prophet Mohammed and his companions"

Table 7. Importance of Reading

\begin{tabular}{|c|c|c|c|c|c|c|c|c|c|c|c|}
\hline \multirow{3}{*}{$\mathrm{NO}$} & \multirow{3}{*}{ Items } & \multicolumn{10}{|c|}{ Importance of Reading } \\
\hline & & \multicolumn{2}{|c|}{$\begin{array}{l}\text { Very } \\
\text { important }\end{array}$} & \multicolumn{2}{|c|}{ Important } & \multicolumn{2}{|c|}{ Neutral } & \multicolumn{2}{|c|}{$\begin{array}{l}\text { Less } \\
\text { important }\end{array}$} & \multicolumn{2}{|c|}{$\begin{array}{l}\text { Not } \\
\text { important }\end{array}$} \\
\hline & & $p$ & $\%$ & $p$ & $\%$ & $p$ & $\%$ & $p$ & $\%$ & $p$ & $\%$ \\
\hline 1. & $\begin{array}{l}\text { To read and understand } \\
\text { religious words and terms } \\
\text { related to Hajj and Omra. }\end{array}$ & 32 & $62.7 \%$ & 12 & $23.5 \%$ & - & - & 5 & $9.8 \%$ & 2 & $3.9 \%$ \\
\hline 2. & $\begin{array}{l}\text { To read and understand words } \\
\text { and texts of general English. }\end{array}$ & 30 & $58.8 \%$ & 14 & $27.5 \%$ & - & - & 3 & 5.9 & 2 & $3.9 \%$ \\
\hline 3. & $\begin{array}{l}\text { To read understand religious } \\
\text { topics and texts related to Hajj } \\
\text { and Omr }\end{array}$ & 32 & $62.7 \%$ & 14 & $27.5 \%$ & - & - & 3 & $5.9 \%$ & 2 & $3.9 \%$ \\
\hline
\end{tabular}

In Table 7, participants were asked to rate the importance of Reading skill in three statements. As shown in table (9), the highest two reasons which scored the same percentage $62.7 \%$ were "To read understand religious topics and texts related to Hajj and Umra" and "To read and understand religious words and terms related to Hajj and Umra". However, the first statement was also reported by $27.5 \%$ of the participants which makes it higher when we combine "very important" and "important" together.

The least reason which received lower rates yet not very significantly different from other reasons was "To read and understand words and texts of general English" where $58.8 \%$ of the participants view it as very important.

In the optional open-ended questions section, a number of participants shared their 
reasons for the importance of reading skill which was mostly related to reading pilgrims' IDs and understanding religious pamphlets, as reported in the following quotes

"To assist lost people through reading their addresses in their IDS"

"To read religious books which are written in English and make sure that they are aligned with the right Islam".

Table 8. Importance of Writing

\begin{tabular}{|c|c|c|c|c|c|c|c|c|c|c|c|}
\hline \multirow{3}{*}{ No } & \multirow{3}{*}{ Items } & \multicolumn{10}{|c|}{ Importance of Writing } \\
\hline & & \multicolumn{2}{|c|}{$\begin{array}{l}\text { Very } \\
\text { important }\end{array}$} & \multicolumn{2}{|c|}{ Important } & \multicolumn{2}{|c|}{ Neutral } & \multicolumn{2}{|c|}{$\begin{array}{l}\text { Less } \\
\text { important }\end{array}$} & \multicolumn{2}{|c|}{$\begin{array}{l}\text { Not } \\
\text { important }\end{array}$} \\
\hline & & $p$ & $\%$ & $p$ & $\%$ & $p$ & $\%$ & $p$ & $\%$ & $p$ & $\%$ \\
\hline 1. & $\begin{array}{l}\text { To write religious } \\
\text { words and terms } \\
\text { related to Hajj and } \\
\text { Omra. }\end{array}$ & 13 & $25.5 \%$ & 9 & $17.9 \%$ & - & - & 3 & $5.9 \%$ & 26 & $51 \%$ \\
\hline 2. & $\begin{array}{l}\text { To write incident } \\
\text { reports. }\end{array}$ & 10 & $19.6 \%$ & 8 & $15.9 \%$ & - & - & 14 & $27.5 \%$ & 19 & $37.3 \%$ \\
\hline 3. & $\begin{array}{l}\text { To write sentences } \\
\text { and short articles. }\end{array}$ & 12 & $23.5 \%$ & 6 & $11.8 \%$ & - & - & 7 & $13.7 \%$ & 26 & $51 \%$ \\
\hline
\end{tabular}

Participants were asked to rate the importance of Writing skill in three statements as shown in Table 8 . The two reasons which scored the same percentage $51 \%$ were "To write religious words and terms related to Hajj and Umra." and "To write sentences and short articles.", and they were considered by the participants as "Not important". The results indicate a low number of participants who view writing skill as either "very important or "important". As shown in table (10), writing skill, in contrast to other previous skills, was not of importance to the participants. As for the statement "To write incident reports", which received $37.3 \%$, if we combine the score of "important $27.5 \%$, it becomes the highest rated statement of a total of $64.8 \%$, followed by a combined statement of "To write sentences and short articles" $64.7 \%$ are closely related. 
Difficulties Faced by RGs in English:

Table 9. Difficulties of English

\begin{tabular}{|c|c|c|c|c|c|c|c|c|c|c|c|}
\hline \multirow{3}{*}{ NO } & \multirow{3}{*}{ Difficulties } & \multicolumn{10}{|c|}{ Level of Agreement } \\
\hline & & \multicolumn{2}{|c|}{$\begin{array}{l}\text { Strongly } \\
\text { agree }\end{array}$} & \multicolumn{2}{|c|}{ Agree } & \multicolumn{2}{|c|}{ Neutral } & \multicolumn{2}{|c|}{ Disagree } & \multicolumn{2}{|c|}{\begin{tabular}{|l} 
Strongly \\
disagree
\end{tabular}} \\
\hline & & $p$ & $\%$ & $p$ & $\%$ & $p$ & $\%$ & $p$ & $\%$ & $p$ & $\%$ \\
\hline 1. & $\begin{array}{l}\text { Difficulty in following } \\
\text { English conversations of } \\
\text { natural } \\
\text { speed }\end{array}$ & 32 & $62.7 \%$ & 11 & $21.6 \%$ & 5 & $9.8 \%$ & 2 & $3.9 \%$ & 1 & $2 \%$ \\
\hline 2. & $\begin{array}{lr}\text { Difficulty } & \text { in } \\
\text { understanding } & \text { different } \\
\text { accents } & \\
\end{array}$ & 33 & $64.7 \%$ & 6 & $11.8 \%$ & 8 & $15.7 \%$ & 3 & $5.9 \%$ & 1 & $2 \%$ \\
\hline 3. & $\begin{array}{l}\text { Difficulty in } \\
\text { understanding } \\
\text { all that is said in English }\end{array}$ & 31 & $60.8 \%$ & 11 & $21.6 \%$ & 8 & $15.7 \%$ & 1 & $2 \%$ & 2 & $3.9 \%$ \\
\hline 4. & $\begin{array}{l}\text { Difficulty in responding } \\
\text { to } \\
\text { all that is said in English }\end{array}$ & 33 & $64.7 \%$ & 6 & $11.8 \%$ & 9 & $17.6 \%$ & 2 & $3.9 \%$ & 1 & $2 \%$ \\
\hline 5. & $\begin{array}{l}\text { Difficulties in using } \\
\text { English due to different } \\
\text { cultures }\end{array}$ & 36 & $70.6 \%$ & 5 & $9.8 \%$ & 7 & $13.7 \%$ & 2 & $3.9 \%$ & 1 & $2 \%$ \\
\hline
\end{tabular}

As shown in Table 9, participants were asked to rate their level of agreement or disagreement with a number of difficulties that are faced in their workplace related to English. As shown in table (11), there was a number of difficulties that scored high percentage by the participants. The highest reported statement was "Difficulties in using English due to different cultures", which scored $70.6 \%$. The second two difficulties that were equally reported with a percentage of $64.7 \%$ were "Difficulty in understanding different accents" and "Difficulty in responding to all that is said in English".

In this optional open-ended questionnaire, a number of GRs shared similar difficulties mentioned in the questionnaire, as shown in the following quotes:

267 | IJET| Volume. 10, Issue 2. December 2021 Copyright Turki alsolami is licensed under Creative Commons Atrribution-ShareAlike 4.0 International License. 
"As an English speaker who speaks English perfectly, I always face problems in understanding articulations of English of Indians, Pakistanis, Indonesians and other Asians"

"I face problems in giving directions and describing object and do my best using my body language"

Level of Importance of English at Work \& Personal Life:

Table 10. Importance of English at Work and Personal life

\begin{tabular}{|c|c|c|c|c|c|c|c|c|c|c|c|}
\hline \multirow{3}{*}{ NO } & \multirow{3}{*}{ Items } & \multicolumn{10}{|c|}{ Level of Importance at Work \& Personal Life } \\
\hline & & \multicolumn{2}{|c|}{$\begin{array}{l}\text { Very } \\
\text { important }\end{array}$} & \multicolumn{2}{|c|}{ Important } & \multicolumn{2}{|c|}{ Neutral } & \multicolumn{2}{|c|}{$\begin{array}{l}\text { Less } \\
\text { important }\end{array}$} & \multicolumn{2}{|c|}{ Not important } \\
\hline & & $p$ & $\%$ & $p$ & $\%$ & $p$ & $\%$ & $p$ & $\%$ & $p$ & $\%$ \\
\hline 1. & $\begin{array}{l}\text { Performing my Job } \\
\text { effectively }\end{array}$ & 40 & $78.4 \%$ & 10 & $19.6 \%$ & - & - & - & - & 1 & $2 \%$ \\
\hline 2. & $\begin{array}{l}\text { Passing } \\
\text { courses }\end{array}$ & 22 & $43.1 \%$ & 14 & $27.5 \%$ & - & - & 5 & $9.8 \%$ & 10 & $19.6 \%$ \\
\hline 3. & $\begin{array}{l}\text { Passing professional } \\
\text { exams and evaluations }\end{array}$ & 17 & $33.3 \%$ & 18 & $35.3 \%$ & - & - & 6 & $11.8 \%$ & 10 & $19.6 \%$ \\
\hline 4. & $\begin{array}{l}\text { Increasing knowledge } \\
\text { in my } \\
\text { Field of specialization } \\
\text { and work }\end{array}$ & 25 & $49 \%$ & 20 & $39.2 \%$ & - & - & 5 & $9.8 \%$ & 1 & $2 \%$ \\
\hline 5. & $\begin{array}{l}\text { Promoting to a higher } \\
\text { position }\end{array}$ & 18 & $35 \%$ & 17 & $33.3 \%$ & - & - & 5 & $9.8 \%$ & 11 & $21.6 \%$ \\
\hline 6. & Increasing stipends & 31 & $60 \%$ & 14 & $27.5 \%$ & - & - & 2 & $3.9 \%$ & 4 & $7.8 \%$ \\
\hline 7. & $\begin{array}{l}\text { Rewarding a } \\
\text { scholarship in an } \\
\text { English-speaking } \\
\text { country }\end{array}$ & 31 & $60 \%$ & 14 & $27.5 \%$ & - & - & 2 & $3.9 \%$ & 4 & $7.8 \%$ \\
\hline 8. & $\begin{array}{l}\text { To speak with non- } \\
\text { Arabic Speakers in } \\
\text { various topics of life }\end{array}$ & 36 & $70.6 \%$ & 7 & $13.7 \%$ & - & - & 4 & $7.8 \%$ & 4 & $7.8 \%$ \\
\hline 9. & $\begin{array}{l}\text { Using the internet to } \\
\text { search the } \\
\text { English websites }\end{array}$ & 34 & $66.7 \%$ & 9 & $17.6 \%$ & - & - & 3 & 5.9 & 5 & $9.8 \%$ \\
\hline
\end{tabular}

In assessing RGs, the importance of English to their personal lives, they were asked to indicate the level of importance of English in nine statements. As shown in Table 10, the highest rate statement by participants was "Performing my Job effectively" which scored 
$78.4 \%$, and we combine the results of expression "agree" $19.6 \%$, the results increased to 98\%. When applying the same to other results the second highest statement is "Increasing knowledge in my field of specialization and work", with its combined result $88 \%$. Other results which scored equally in combination of "very important" and "important" were the statements: "Increasing stipends" and "Rewarding a scholarship in an Englishspeaking country" which were 87.5. In addition, the statements "To speak with nonArabic Speakers in various topics of life" and "Using the internet to search the English websites" scored $84.3 \%$. All these results indicate that participants highly value the importance of English for the various reasons as reported in the questionnaire.

\section{Activities needed in English}

Table 11. Activities Needed in English

\begin{tabular}{|c|c|c|c|c|c|c|c|c|c|c|c|}
\hline \multirow{3}{*}{ No } & \multirow{3}{*}{ Activities needed in English } & \multicolumn{10}{|c|}{ Level of Agreement } \\
\hline & & \multicolumn{2}{|c|}{$\begin{array}{l}\text { Strongly } \\
\text { agree }\end{array}$} & \multicolumn{2}{|c|}{ Agree } & \multicolumn{2}{|c|}{ Neutral } & \multicolumn{2}{|c|}{ Disagree } & \multicolumn{2}{|c|}{$\begin{array}{l}\text { Strongly } \\
\text { disagree }\end{array}$} \\
\hline & & $p$ & $\%$ & $p$ & $\%$ & $p$ & $\%$ & $p$ & 5 & $P$ & $\%$ \\
\hline 1. & $\begin{array}{l}\text { Eliciting information of } \\
\text { identities of non-Arabic } \\
\text { speakers }\end{array}$ & 38 & $74.5 \%$ & 10 & $19.6 \%$ & - & - & 2 & $3.9 \%$ & 1 & $2 \%$ \\
\hline 2. & $\begin{array}{l}\text { Discussing religious issues } \\
\text { related to performing rituals }\end{array}$ & 45 & $88.2 \%$ & 4 & $7.8 \%$ & 1 & $2 \%$ & - & - & 1 & $2 \%$ \\
\hline 3. & $\begin{array}{l}\text { Giving clear directions of } \\
\text { inquired locations }\end{array}$ & 44 & $86.3 \%$ & 8 & $11.8 \%$ & - & - & - & - & 1 & $2 \%$ \\
\hline 4. & Investigating incidents & 16 & $31.4 \%$ & 12 & $23.5 \%$ & 16 & $31.4 \%$ & 6 & $11.8 \%$ & 1 & $2 \%$ \\
\hline 5. & $\begin{array}{lll}\begin{array}{l}\text { Providing } \\
\text { assistances }\end{array} & \text { helps } & \text { and }\end{array}$ & 47 & $92.2 \%$ & 3 & $5.9 \%$ & - & - & - & - & 1 & $2 \%$ \\
\hline 6. & $\begin{array}{l}\text { Inquiring about descriptions } \\
\text { of missing objects, values, } \\
\text { and missing circumstances }\end{array}$ & 44 & $86.3 \%$ & 4 & $7.8 \%$ & 2 & $3.9 \%$ & - & - & 1 & $2 \%$ \\
\hline 7. & $\begin{array}{l}\text { Inquiring about descriptions } \\
\text { missing people }\end{array}$ & 44 & $86.3 \%$ & 4 & $7.8 \%$ & 2 & $3.9 \%$ & - & - & 1 & $2 \%$ \\
\hline 8. & $\begin{array}{l}\text { Collaborating } r \\
\text { communicating with non- } \\
\text { Arabic speaking embassies } \\
\begin{array}{l}\text { and } \\
\text { representatives }\end{array}\end{array}$ & 43 & $84.3 \%$ & 6 & $11.8 \%$ & 1 & $2 \%$ & - & - & 1 & $2 \%$ \\
\hline
\end{tabular}

269 | IJET| Volume. 10, Issue 2. December 2021 Copyright Turki alsolami is licensed under Creative Commons Atrribution-ShareAlike 4.0 International License. 
Participants, were asked to report their level of agreement or disagreement on the needed activities of English. As shown in Table 11 the highest reported activity was "Providing helps and assistances" which scored 92.2\%. The second reported activity was "Discussing religious issues related to performing rituals", which scored $88.2 \%$. The third highly reported activities were "Inquiring about descriptions of missing objects, values, and missing circumstances" and "Inquiring about descriptions missing people". Another high reported activity which scored $84.3 \%$ was "Collaborating and communicating with non-Arabic speaking embassies and consulates' representatives". The activity "Investigating incidents" was significantly reported by the participants which scored $31.4 \%$.

Open-ended questions from the questionnaire

In the last section of the questionnaire, an open-ended question was given to RGs to provide any suggestion to improve the situation of English language education in their sector. A number of RGs shared their views which indicate the need of English to perform their religious obligations better as shown in the following quotes:

\footnotetext{
"There is an extreme and urgent need to learn English and improve our communication abilities"

"To help pilgrims clarifying the right way of Islam and Prophet Mohammed peace be upon him, and we should not remain silent because of not knowing English"

"Communicating in English abilities are prime important to start

Dialogue to correct some misunderstood concepts"
}

\section{Discussion}


The main aim of this study was to identify English language needs of the staff of the Presidency of The Grand Mosque in the holy city of Makkah. The study adopted a quantitative method research design. A questionnaire was filled out by 51 participated in the questionnaire.

Regarding the importance of English to be used in RGs at The Grand Mosque and the reasons for its importance, it is clear that participants reached almost a consensus with 98\% confirming English is needed in their workplace "Holy Mosque", and it is very frequent. This percentage indicates that English is extremely important for RGs, and this is in line with previous studies which indicated the importance of English in professional life (Abdellah \& Ibrahim, 2013; Alhamami, 2020;). Participants seem to highly regarded English as important to their work for various reasons such as a medium of communication to help pilgrims who do not speak Arabic in advising them about places, rituals, and directions around The Grand Mosque. In addition, English is highly regarded because it is also used to preach Non- Arabic Muslim speakers. This highlights the importance of English to deliver the words of Allah to a wider audience and preach nonArabic speakers of worshipers in the holy cities (Abdellah \& Ibrahim, 2013).

The significant result on the importance of English is aligned with ESP framework that employees, who work in service industries which The Grand Mosque is a part of Hajj and Umra industry of those industries. They need English language to provide services to guests who cannot speak Arabic language (Abdellah \& Ibrahim, 2013; Samer, 2014). Abdellah and Ibrahim (2013), point that it is crucial for Hajj guides to speak English .The 
Prophet' Mosque visitors are mostly has the same characteristic of visitors of The Grand Mosque because those visitors come to The Grand Mosque for Hajj or Omra, and when they finish, they go to the Prophet Mosque for visitation.

Findings of the questionnaire reveals that the most highly needed English language skills in RGs' jobs are listening and speaking. This is in line with ESP theory that English for Occupational Purposes (EOP) emphasizes more on "listening" and "speaking" as they represent the spontaneous communicative skills which enable interlocutors of different native languages negotiate information at workplace successfully. These findings are similar to other studies which were conducted on other Muslim contexts (Abdellah \& Ibrahim, 2013; Sahiba \& Mirza, 2019; Samer, 2014).

Reading skill was also highlighted as an important skill for RGs which was shown in the questionnaire. Participants need reading skills to read and understand the publications written in English which are brought with pilgrims and visitors because most of the time these publications violate religious rules. This is in a line with a previous study (Ahmad \& Khushi, 2014), where reading was found to be an important skills for an Islamic preacher. Their study suggested that reading materials should include authentic Islamic texts to enable the preachers to understand the English translated vocabularies related to religious matters.

One of the research questions of this study was to tackle the issues of difficulties faced by RGs. Findings indicate that one of the major issues for RGs is poor English level. This result was evident in the questionnaire when they were asked to indicate their levels in English. This can be linked to lack of English training courses in their sector which was 
mentioned by a number of participants. Similar findings were also reported by (Samer, 2014) where due to the low level of the Hajj volunteers, it created a stressful communication between them and the pilgrims.

One of the issues that was reported by a number of participants, particularly with higher level of English, was Pilgrims English accent. They indicate that the accent hinders them from understanding pilgrims' English inquires. Similar finding was found in a previous study (e.g., Samer, 2014). Abdellah and Ibrahim (2013) recommend that accents and pronunciations should be considered in designing a course for Hajj guides in Almadina city.

The importance of English for professional purposes was one of the themes identified in this study. In the questionnaire, the findings indicate that the highest two reasons for the need of English in RGs jobs was to perform their jobs effectively and to increase their knowledge when to deal with non-Arabic speakers. This is can be linked to a religious duty to serve the visitors of The Grand Mosque. Similar findings were voiced other studies in Muslim contexts where they wanted to broadcast and communication English to the world (Abudhahir \& Ali, 2018; Sahiba \& Mirza , 2019; Samer, 2014). It can be argued that some of the tasks particularly asking and responding to inquiries are shared with RGs working at The Grand Mosque, however, the nature and types of questions are more complex, religiously focused, and require sometimes a high command of English.

The nature and types of English language activities and tasks for RGs were also explored in this study. The questionnaire results show that English is extremely needed by RGs in preaching and advising, answering inquiries, and giving directions which were the most 
frequently mentioned situations. In The context of The Grand Mosque, the main tasks of RGs are all about preaching and advising those visitors who are in need. e.g., how to perform certain rituals or advising wrongdoers, giving directions and replying on visitors' inquiries are the key tasks for RGs' jobs. If their English level is not as high as it is expected to be, this as a result will affect their performance. As some previous studies indicated, the nature of activities and materials for Islamic guidance or advising should focus on authentic materials taken from Quran or Prophet Sayings or other religious publication such as commentaries, and the nature of activities should be more communicative e.g., role-playing (Abudhahir \& Ali, 2018; Ahmad \& Khushi, 2014).

\section{CONCLUSION}

This study is of an importance to a sector in Saudi Arabia that serves the pilgrims, and the government has been doing its utmost to provide the best services. This study and based on the findings, have the following suggestions in this regard:

1) Religious Guides at The Grand Mosque need an urgent intensive English course.

2) This course should start from basic English as the study sample lacks basic English.

3) This course should focus more on "listening" and "speaking" with less emphasis on "reading".

4) This course should be designed around ERP, rituals, sacred places, requisites, Sharia provisions and so on without ignoring general English like giving directions and asking for information.

274 | IJET | Volume. 10, Issue 2. December 2021 Copyright Turki alsolami is licensed under Creative Commons Atrribution-ShareAlike 4.0 International License. 
5) Using the holistic qur'anic and Hadith verses as demonstrative examples.

6) This course should highlight the differences among English accents. 
7) Grammar Translation Method (GTM) teaching approach is strongly advised to teach

RGs as they are below beginner level. When RGs' levels improve, it is advised to change to audiolingual approach, then to Communicative Language Teaching (CLT).

8) This course should be updated periodically, until it reaches validity, then it should be a requirement for new RGs' employment.

\section{References}

Abdellah, A., \& Ibrahim, M. (2013). Towards developing a language course for Hajj guides in al-madinah al-munawwarah, a needs assessment. International Education Studies, 6(3). https://doi.org/10.5539/ies.v6n3p192

Abudhahir, R. A., Mahdun, M., \& Nor, R. M. (2015). Need Analysis and Material Development in English for Specific Purposes in Relation to English for Islamic Studies. Journal of Management \& Muamalah, 5(2).

Ahmad, N., \& Khushi, Q. (2014). An Analysis of Religious Scholars' Needs for Reading Religious Texts Written in English. Pakistan Journal of Islamic Research, 14(14), 113-121.

Aldohon, H. I. (2014). English for specific purposes (ESP) for Jordanian tourist police in their workplace: Needs and problems. International Education Studies, 7(11). https://doi.org/10.5539/ies.v7n11p56

Al-Gorashi, A. K. (1988). The English communication needs of military cadets in Saudi Arabia as perceived by junior officers in the Saudi Army and air defense [Unpublished doctoral dissertation]. Indiana University.

Alhamami, M. (2020). Language barriers in multilingual Saudi hospitals: Causes, consequences, and solutions. International Journal of Multilingualism, 17(2), 113. https://doi.org/10.1080/14790718.2020.1777134

Alhuqbani, M. B. (2008). Identifying the English Language Needs of Saudi Police Officers. Journal of the Saudi Association of Languages and Translation, 1(2), 55-97.

Bhatia, V. K. (2015). Critical genre analysis. Hermes - Journal of Language and Communication in Business, 54, 9-20. https://doi.org/10.4324/9781315690315

Brown, J. D. (2009). Foreign and second language needs analysis. In M. H. Long, \& C, Doughty (Eds.), The handbook of language teaching (pp. 269-293). WileyBlackwell.

Brown, J. D. (2016). Introducing needs analysis and English for specific purposes. Routledge.

276 | IJET | Volume. 10, Issue 2. December 2021

Copyright Turki alsolami is licensed under Creative Commons Atrribution-ShareAlike 4.0 International License. 
Chambers, F. (1980). A re-evaluation of needs analysis in ESP. The ESP Journal, 1(1), 25-33. https://doi.org/10.1016/0272-2380(80)90007-4

Dudley-Evans, T., John, M. J., \& John, M. J. (1998). Developments in English for specific purposes: A multi-disciplinary approach. Cambridge University Press.

Hutchinson, T., \& Waters, A. (1987). English for specific purposes. Cambridge University Press.

Jordan, R. R. (1997). English for academic purposes: A guide and resource book for teachers. Cambridge University Press.

Juhary, J. B. (2013). Using Military Vocabulary and Concepts for Successful Language Learning at the Defence University. Literacy Information and Computer Education Journal, 4(3).

Muhammad, I., \& Halim Abdul Raof, A. (2019). Assessing the ESP needs of Saudi engineering undergraduates: A diagnostic view. Arab World English Journal, 10(4), 204-222. https://doi.org/10.24093/awej/vol10no4.16

Munby, J. (1981). Communicative syllabus design: A sociolinguistic model for designing the content of purpose-specific language programmes. Cambridge University Press.

Richterich, R., \& Chancerel, J. (1980). Identifying the needs of adults learning a foreign language. Pergamon Press.

Robinson, R. (1991). ESP Today: A Practitioner's Guide. Hemel Hempstead. Prentice Hall.

Sahiba, A., \& Mirza, A. A. (2019). Investigating students' belief toward the importance of English learning for dakwah activity at IAIN Palangka Raya. In The 3rd INACELT (International Conference on English Language Teaching). Institut Agama Islam Negeri (IAIN) Palangka Raya Indonesia.

Samer, A. K. (2014). Spoken English for Saudi Hajj volunteers: A need assessment [Unpublished master's thesis]. Spoken English for Saudi Hajj volunteers: A need assessment.

Sayed Abudhahir, R. A., \& Mohamad Ali, A. (2018). English for Islamic studies: Should I learn English? - From the eyes of Islamic studies students. LSP International Journal, 5(1). https://doi.org/10.11113/1spi.v5n1.65

Swales, J. M. (1990). Discourse analysis in professional contexts. Annual Review of Applied Linguistics, 11, 103-114. https://doi.org/10.1017/s0267190500001987

Tarihoran, N., \& R. (2019). Exploring the Islamic culture in English for Islamic studies (EIS) classroom. Proceedings of the 4th ASEAN Conference on Psychology, Counselling, and Humanities (ACPCH 2018). https://doi.org/10.2991/acpch18.2019 .3

West, R. (1994). Needs analysis in language teaching. Language Teaching, 27(1), 119. https://doi.org/10.1017/s0261444800007527

277 | IJET | Volume. 10, Issue 2. December 2021

Copyright Turki alsolami is licensed under Creative Commons Atrribution-ShareAlike 4.0 International 